Sains Malaysiana 49(9)(2020): 2231-2236

http://dx.doi.org/10.17576/jsm-2020-4909-20

\title{
Preparation and Characterization of Chitosan-Coated Oleic Acid Liposomes for Intravenous Delivery
}

(Penyediaan dan Pencirian Liposom Asid Oleik Bersalut Kitosan untuk Penghantaran Intravena)

\author{
Noor Ashyfiyah Basrowi, Vicit Rizal Eh Suk, Rahadian Permadi \& Misni Misran*
}

\begin{abstract}
Liposome has been studied as a potential carrier for targeting and controlled drug delivery. However, poor stability remains a challenge because it can lead to drug leakage from the vesicles thus reduce the effectiveness towards the target cell. For this aim, the present study incorporated the low molecular weight chitosan (LMWC) into the oleic acid liposome to maintain the stability and prolong the lifetime in the blood circulation. The thin-film hydration method was employed to prepare the oleic acid liposomes prior to coating them with LMWC. The stability of the liposomes was determined by the measurement of particle size and zeta potential for 28 days. The morphology of the liposome was confirmed by observing the shape under transmission electron microscopy (TEM) and it showed almost spherical in shape. The average particle size increased to $201.23 \mathrm{~nm}$ and $-51.4 \mathrm{mV}$ when $5 \mathrm{mg}$ of LMWC was added to the oleic acid liposome. The increase of particle size and zeta potential of LMWC-coated liposome indicated that polymer-liposome interaction had changed the stability of liposome thus this invention could be useful for delivering active ingredients through intravenous delivery.
\end{abstract}

Keywords: Itraconazole; liposome; low molecular weight; oleic acid

ABSTRAK

Liposom sedang dikaji sebagai sebuah pengangkut yang berpotensi tinggi bagi penyasaran dan pengawalan penghantaran ubat. Walau bagaimanapun, mengekalkan kestabilannya merupakan satu cabaran kerana ia boleh menyebabkan ubat terkeluar dari vesikel serta mengurangkan keberkesanan terhadap sel yang hendak disasarkan. Kajian ini bermatlamat untuk menyalutkan kitosan berjisim molekul rendah ke dalam liposom asid oleik untuk mengekalkan kestabilan dan jangka hayatnya dalam peredaran darah. Kaedah penghidratan lapisan nipis digunakan untuk menghasilkan liposom asid oleik sebelum disalut dengan kitosan berjisim molekul rendah. Kestabilan liposom ditentukan dengan mengukur saiz zarah dan potensi zeta selama 28 hari. Morfologi liposom ditentukan dengan memerhatikan bentuk di bawah mikroskop elektron transmisi dan menunjukkan bentuk seakan bentuk sfera. Purata saiz zarah meningkat kepada $201.23 \mathrm{~nm}$ dan -51.4 mV apabila $5 \mathrm{mg}$ kitosan telah ditambahkan ke liposom asid oleik. Peningkatan saiz zarah dan potensi zeta bagi liposom bersalut kitosan berjisim molekul rendah menunjukkan bahawa interaksi polimer dan liposom telah mengubah kestabilan liposom dan penemuan ini berpotesi untuk menyampaikan bahan aktif secara penghantaran intravena.

Kata kunci: Asid oleik; Itraconazole; kitosan berjisim molekul rendah; liposom

\section{INTRODUCTION}

Liposome was derived from the combination of two Greek words, 'lipos' meaning fat and 'soma' meaning body. It was first discovered by Alec D Bangham and his coworkers in 1963 (Bangham \& Horne 1964). It was invented to improve the effectiveness of the established drugs by modifying the drug absorption, reducing the metabolism, prolonging biological half-life, or reducing toxicity. Lipids that forming liposome can be from the natural or synthetic, as long as it is biocompatible and biodegradable. Besides, lipids are able to compartmentalize and solubilize both hydrophilic and hydrophobic materials by nature because they made up of lipids which are amphiphilic molecules (Çağdaş et al. 2014).

The stability in terms of the particle size and the ability to remain suspended in solution during prolonged storage is the important properties to be considered in developing the liposome formulation (Teo et al. 2011). In 
order to achieve stability, one of the potential solutions by coating them with a polymer. Modification of the structure and surface of liposome have been discovered to generate liposomes with specific biological effects where it will contribute to the application of liposome in biomedicine (Li et al. 2019). There are various polymers that being investigated as a potential coating material for liposomes such as polyethylene glycol, alginate, dextran, pectin, gelatin, and chitosan.

In this study, chitosan, which is a linear biopolymer that composes of units of d-glucosamine and $N$-acetyld-glucosamine that linked by a glycosidic $\beta(1-4)$ bond and it is derived from the partial deacetylation of chitin which is extracted from the crustacean shells (Baldrick 2010) has been selected due to their natural occurrence and high biocompatibility. The molecular structure of the chitosan has an amino group (C2) and 2 hydroxyl group (C3 and C6) and the molecular weight ranges from 10000 to 1 million Daltons (Sánchez-machado et al. 2019). Furthermore, chitosan has good biodegradability and low toxicity that makes it suitable for being used in biomedical and pharmaceutical formulations especially in drug delivery (Wilson et al. 2010).

Liposomes have been prepared by employing the dry lipid film hydration method, which is the most common technique to prepare liposomes. The stability of oleic acid liposomes as a result of the amount of coating material, has been investigated in the aim to optimize the amount of LMWC in the formulation. A hydrophobic antifungal and antiviral drug, namely Itraconazole was encapsulated in the bilayer membrane of liposomes. Itraconazole is known as active triazole derivative drugs that have a broad spectrum of activity. This drug acts against commonly found pathogens like Candida spp. and also possesses as antiviral to inhibit viral infection such as Feline coronavirus (Takano et al. 2019) and Echovirus (Lee et al. 2017). There is an intravenous formulation of Itraconazole that had been developed by the researchers and this formulation had improved the absorption and bioavailability of the drug compared to the original capsules formulation (Ling et al. 2016). The compatibility of the drug with the liposome formulation has been studied. The in vitro drug release study was quantified by using Franz diffusion cell paired with a UV-Visible spectrophotometer.

\section{MATERIALS AND METHODS}

\section{MATERIAL}

Oleic acid and Itraconazole was purchased from Sigma (St. Louis, USA). Chloroform was purchased from Merck (Germany). Sodium hydroxide $(\mathrm{NaOH})$ was purchased from Sigma-Aldrich (St. Louis, USA), while hydrochloric acid $37 \%$ and phosphate buffered saline tablet was purchased from Spectrum (New Brunswick, NJ). Immersion oil was purchased from Merck (Germany). Itraconazole and folinic acid calcium salt hydrate were purchased from Sigma (St. Louis, USA).

\section{PREPARATION OF LMWC-OLEIC ACID LIPOSOME}

Liposomes were prepared by using the thin-film hydration method. Oleic acid was weighed using a weighing balance (Denver Instrument, US) and dissolved in $5 \mathrm{~mL}$ chloroform. The mixture was homogenized using a JAC ultrasonic 1505 bath sonicator (Jeio Tech, Korea). The solution was transferred into $100 \mathrm{~mL}$ round bottom flask and the chloroform was removed by using Büchi ${ }^{\circledR}$ R114 rotary evaporator (USA) equipped with a water bath under reduced pressure. The thin-lipid film was rehydrated with warm phosphate buffer saline (PBS) to the desired concentration. The $\mathrm{pH}$ of the solution was adjusted to pH7.4 by using $0.1 \mathrm{M}$ hydrochloric acid $(\mathrm{HCl})$ or sodium hydroxide $(\mathrm{NaOH})$. Meanwhile, a different amount of LMWC was dissolved in PBS separately prior to coat the oleic acid liposome and stirred overnight.

\section{MORPHOLOGICAL OBSERVATION VIA TRANSMISSION ELECTRON MICROSCOPY (TEM)}

HR-TEM JEM2100F (JEOL, USA) equipped with Gatan software (Gatan Inc, USA) and an accelerating voltage of $200 \mathrm{kV}$ at Faculty of Medicine, University of Malaya had been used to observe the morphology of the liposome. A drop of the sample was introduced into a 400 mesh copper-coated carbon grid and excess liquid was removed using a clean filter paper. The grid was stained with $1 \%$ phosphotungstic acid and the excess staining agent was removed using a clean filter paper. The copper-coated carbon grid which contained the sample was air dried by placing it in the desiccator for $24 \mathrm{~h}$.

\section{ZETA POTENTIAL AND PARTICLE SIZE}

The particle size and zeta potential were measured by using a Zetasizer NanoZS (Malvern Instruments Ltd., United Kingdom) equipped with $4 \mathrm{~mW}$ HE-NE laser at $633 \mathrm{~nm}$ in Fundamental and Frontier Science in Nanostructure Self Assembly (FSSA). $1 \mathrm{~mL}$ sample was added into four-sided clear polystyrene cuvette to measure the particle size while $1 \mathrm{~mL}$ was injected into polycarbonate with gold plated folded capillary cell electrode to measure the zeta potential. All measurements were carried out in triplicate at $25^{\circ} \mathrm{C}$.

\section{ENCAPSULATION EFFICIENCY}

An appropriate amount of Itraconazole was dissolved in phosphate buffer $\mathrm{pH} 7.4$. The drug solutions were introduced to the round bottom flask that contains dry lipid film composed of oleic acid during the hydration. 
The resulting mixture was adjusted to $\mathrm{pH} 7.4$ using an appropriate amount of $0.1 \mathrm{M}$ hydrochloric acid $(\mathrm{HCl})$ or sodium hydroxide $(\mathrm{NaOH})$ and kept overnight. One $\mathrm{mL}$ sample was transferred to a Vivaspin centrifugal unit with a molecular weight cut off (MWCO) of $10 \mathrm{kDa}$ (Satorius Stedim, Vilvoorde, Belgium) and centrifuged at $1500 \mathrm{rpm}$ using velocity $18 \mathrm{R}$ refrigerated centrifuge (Dynamica Scientific Ltd., United Kingdom) for 15 min at $25 \pm 1{ }^{\circ} \mathrm{C}$. The absorbance of the free drug discarded was measured using a UV-vis spectrophotometer (Agilent Technologies, USA). The encapsulation efficiency (EE \%) was calculated using (1):

$$
\% E E=\left[100-\left(\frac{F}{T} \times 100\right)\right]
$$

where $F$ is the amount of free drug; and $T$ is the total amount of drug added into the oleic acid liposome.

\section{IN-VITRO DRUG RELEASE STUDY}

The in vitro release of Itraconazole from the LMWCcoated oleic acid liposome was carried out using an automated Franz Diffusion Cell System (Hanson Research Co., USA). The receptor chambers were prefilled with media (PBS, pH7.4). The cellulose dialysis membranes $5 \mathrm{kDa}$ MWCO (The Nest Group Inc, USA) were placed on top of the receptor chambers followed by the donor chamber. An amount of $1 \mathrm{~mL}$ of LMWC-coated oleic acid liposome encapsulating Itraconazole was introduced into the donor chambers with stirring at $400 \mathrm{rpm}$ and a controlled temperature of $37 \pm 1{ }^{\circ} \mathrm{C}$. The eluent was collected at $0.5,1.0,2.0,4.0,6.0,8.0,12.0,16.0,20.0$, and $24.0 \mathrm{~h}$ and quantified using calibration curve.

\section{RESULTS AND DISCUSSION}

\section{MORPHOLOGICAL OBSERVATION VIA TRANSMISSION ELECTRON MICROSCOPY (TEM)}

The morphology of the liposome was observed by using TEM. The TEM images indicated that the liposomes formed were almost spherical in shape (Figure 1(a) and 1(b)). The size of the oleic acid liposomes much smaller compared to the size of the liposome that coated with LMWC. This result was comparable to the particle size that was measured by using Zetasizer NanoZS. Furthermore, the irregular structure of LMWC-oleic acid liposome indicated that the existence of LMWC surrounding the liposomes. The polymer that coated the liposome would depend on the ability of the polymer to adhere to the lipid bilayer (Mady et al. 2009).

\section{AVERAGE PARTICLE SIZE AND ZETA POTENTIAL}

Figure 2 shows the average particle size of liposomes as incubated for 28 days. The average particle size of oleic acid liposome coated with LMWC showed a larger size compared to the oleic acid liposome. The combination of adsorption coagulation and bridging between the chitosan and liposomes causes the interaction between them thus increasing the size of the liposome (Mady \& Darwish 2010). The size of liposomes that coated with 5 and $10 \mathrm{mg}$ of LMWC did not show significant changes within 28 days of storage time. The particle size of liposome coated with 5 and $10 \mathrm{mg}$ LMWC is 201.23 and $238.43 \mathrm{~nm}$, respectively. These results showed that 5 and $10 \mathrm{mg}$ of LMWC was sufficient to stabilize the oleic acid liposome. However, the average particle size of liposome that coated with 20 and $40 \mathrm{mg}$ of LMWC was increased dramatically after the $21 \mathrm{st}$ day from 213.60 to $518.13 \mathrm{~nm}$ and 206.87 to $762.53 \mathrm{~nm}$, for 20 and $40 \mathrm{mg}$ LMWC, respectively. This phenomenon has occurred may be due to the presence of excess chitosan that promotes the coagulation process might contribute to the increased of the liposome size (Tan \& Misran 2013). However, on the 28th day, the particle size of 20 and $40 \mathrm{mg}$ LMWColeic acid liposome decreased. The formation of more chitosan layers on the surface of the liposome caused the weak interaction between the chitosan and the head group of the lipid which leads to the breakage of the liposome membrane. This phenomenon leads to the instability of the liposome and decreased particle size (Mertins \& Dimova 2013).

The surface modification of oleic acid liposome by coating with LMWC was evaluated by comparing the zeta potential on the 1st and 28th day. Table 1 shows that the zeta potential of oleic acid and LMWC-coated oleic acid was negatively charged. On day 1 , the oleic acid liposome and the liposome that contained $5 \mathrm{mg}$ LMWC resulted in the most negative zeta potential. Besides, the increasing amount of LMWC added to the oleic acid liposome had increased the zeta potential from -64.8 to $-32.7 \mathrm{mV}$. The elevated zeta potential was due to the condensed chitosan that adsorbed to the liposomal surface since chitosan carriers a positive charge. (Mady \& Darwish 2010). On the 28th day, the most negative zeta potential was oleic acid liposome and increased with an increasing amount of LMWC added to the oleic acid liposome. Increased zeta potential resulting in greater repulsion between particles, thus lead to a more stable colloidal dispersion (Mady et al. 2009).

\section{ENCAPSULATION EFFICIENCY}

The liposome can carry both hydrophilic and hydrophobic drugs which can increase the effectiveness of drugs towards the target cell. Furthermore, the closed structure of the vesicles which consist of one or more lipid bilayers that surrounded the inner aqueous compartment allows both hydrophilic and lipophilic drugs to be effectively encapsulated (Jaafar-maalej et al. 2010). 
Figure 3 shows the encapsulation efficiency of Itraconazole in a LMWC-oleic acid liposome. The LMWColeic acid liposomes were successfully encapsulated more than $90 \%$ of Itraconazole that was introduced into the formulation. This is due to the hydrophobicity of Itraconazole will spontaneously embedded Itraconazole within the liposome bilayers (Jaafar-maalej et al. 2010; Toniazzo et al. 2017). The incorporation of LMWC in the formulation showed a minimal effect on the encapsulation efficiency of Itraconazole in the formulated liposomes, where it was $94 \%$ in oleic acid liposomes, and the highest was $96 \%$ when the amount of LMWC is $5 \mathrm{mg}$.

\section{IN-VITRO RELEASE STUDY OF ITRACONAZOLE}

The drug release study was carried out on five different formulations that different amounts of LMWC added in the oleic acid liposomes. The studied formulas were selected to investigate the impact of LMWC-coated oleic acid on drug release. Figure 4 shows the cumulative release of Itraconazole into the diffusion cells. In vitro release of bare Itraconazole after $24 \mathrm{~h}$ was $70.3 \%$ and significantly reduced to $2.6 \%$ in oleic acid liposomes. Incorporation of LMWC in the formulation affecting the in vitro release of Itraconazole. The result obtained might be attributed to the disruption of the lipid bilayer membrane, the structure and fluidity of the lipid bilayers that further effects the release of the drug from the liposomes (Hardiansyah et al. 2017). Formulation with $5 \mathrm{mg}$ LMWC showed the least release at $3.7 \%$ after $24 \mathrm{~h}$ while formulation with 10 mg LMWC showed the highest in vitro release at $27.1 \%$. This showed that the incorporation of LMWC promoted the release of Itraconazole to the environment. Other than that, the permeability of the liposome by the addition of the polymer could promote the diffusion of the hydrophilic drug more favorable which made the release was higher (Suk \& Misran 2017). However, the drop in the cumulative in vitro release of Itraconazole has occurred with the (a) Oleic acid liposome

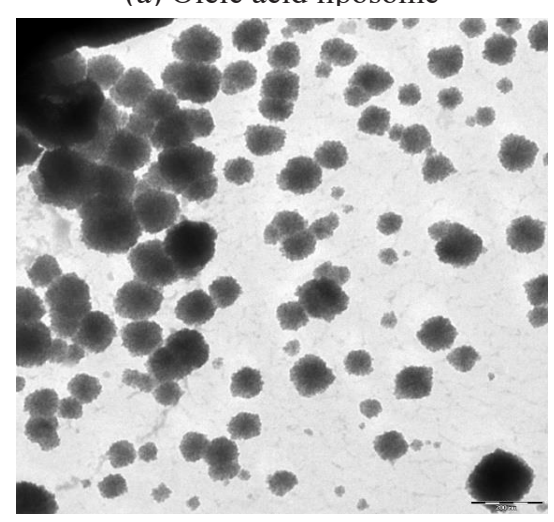

(b) chitosan-oleic acid liposome

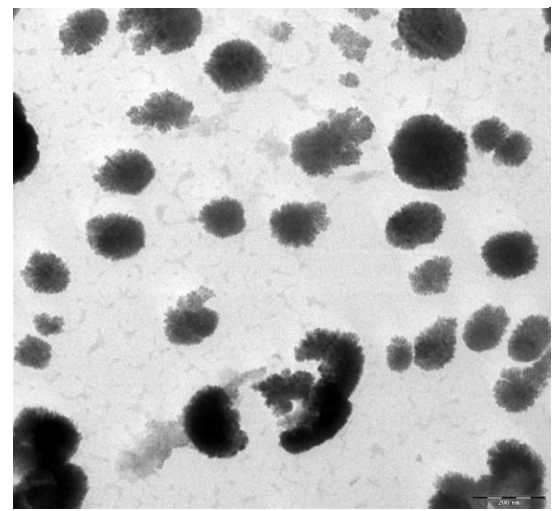

FIGURE 1. TEM micrograph of (a) oleic acid liposome and (b) LMWColeic acid liposome. The scale was $200 \mathrm{~nm}$

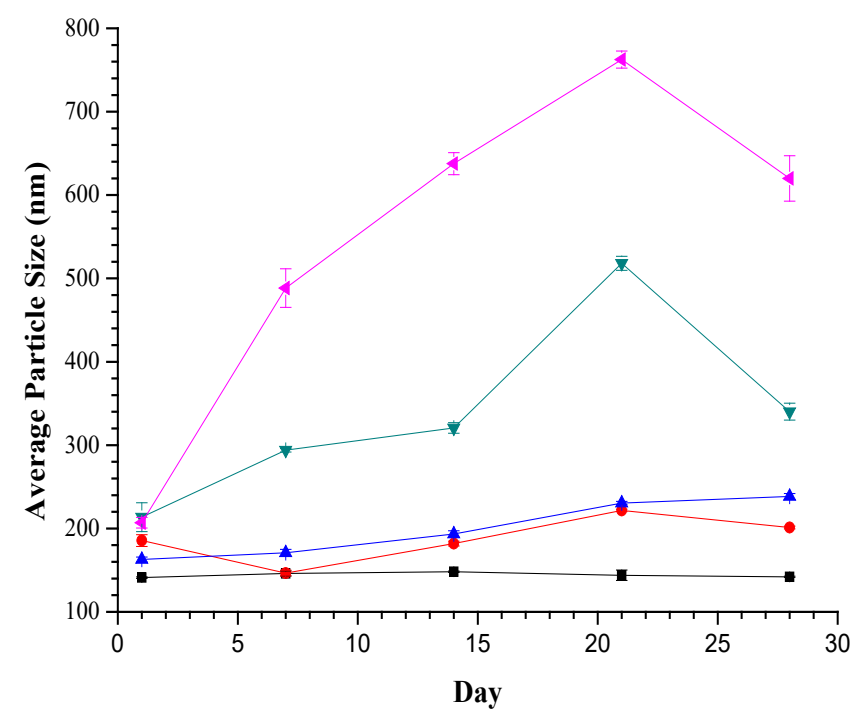

FIGURE 2. The average particle size of LMWC-oleic acid liposomes at $25^{\circ} \mathrm{C}$. The amount of LMWC added to oleic acid liposome

$0(\mathbf{\square}), 5(\bullet), 10(\mathbf{\Delta}), 20(\varangle)$, and $40 \mathrm{mg}(\nabla)$ 
further addition of LMWC, which may be due to the concentrated polymeric chain of LMWC at the surface of liposomes became a protective barrier that prevents Itraconazole from released into the environment.

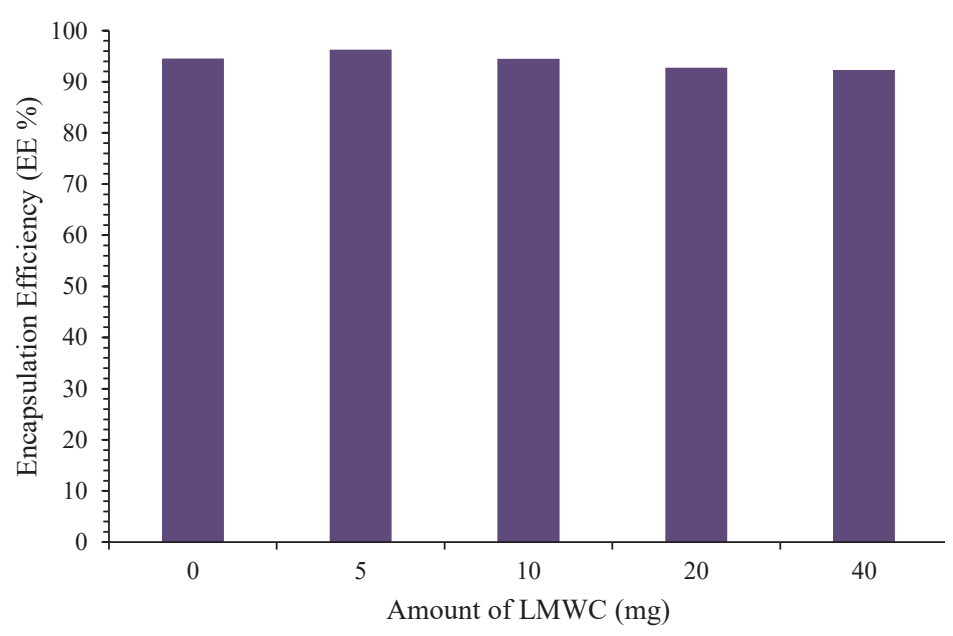

FIGURE 3. Encapsulation Efficiency (\%) of Itraconazole at different amounts of LMWC added into the oleic acid liposome. Measurement was taken in triplicate with a standard deviation of less than 1.0

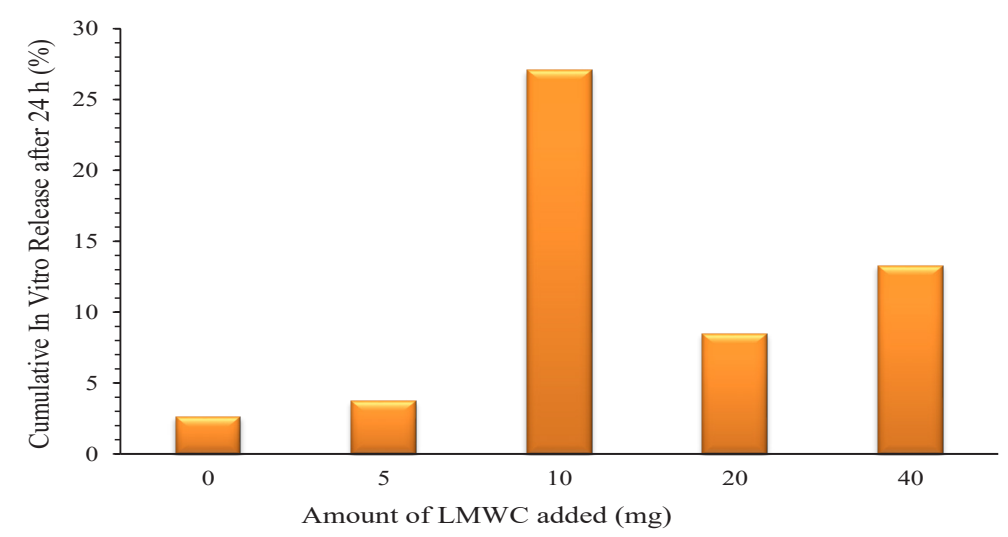

FIGURE 4. In vitro release study of Itraconazole from LMWC-oleic acid liposome. Measurement was taken in triplicate with a standard deviation of less than 1.0

TABLE 1. Zeta potential of LMWC-oleic acid liposome

\begin{tabular}{ccc}
\hline \multirow{2}{*}{$\begin{array}{c}\text { Amount of LMWC added into the oleic acid } \\
\text { liposome (mg) }\end{array}$} & \multicolumn{2}{c}{ Average zeta potential (mV) } \\
\cline { 2 - 3 } 0 & Day 1 & Day 28 \\
\hline 5 & -61.6 & -62.3 \\
10 & -64.8 & -51.4 \\
20 & -53.6 & -41.6 \\
40 & -54.2 & -39.8 \\
\hline
\end{tabular}




\section{CONCLUSION}

The oleic acid liposomes coated with different amounts of LMWC were successfully prepared by employing a thin lipid hydration method. It has been demonstrated that oleic acid liposome added with $5 \mathrm{mg}$ LMWC was the best formulation due to its stability where the particle size and zeta potential are $201.23 \mathrm{~nm}$ and $-51.4 \mathrm{mV}$, respectively. Based on the micrograph obtained from the TEM, the LMWC-oleic acid liposomes formed almost spherical in shape. The high encapsulation efficiency of Itraconazole and reduced drug release profile showed a slow-released where less than $40 \%$ of drugs released after $24 \mathrm{~h}$. These data demonstrated that LMWC-liposome interaction had affected the stability of liposome thus this invention could be useful for delivering hydrophobic active ingredients. The LMWC-oleic acid liposome could be further investigated as an effective and potential intravenous drug delivery.

\section{ACKNOWLEDGEMENTS}

This work was fully supported by the University of Malaya through Research Grant (GPF065B-2018, FP0752018A, and PR002-2018A). The authors would like to thank our friends from Colloid Laboratory, Department of Chemistry, UM, Faculty of Medicine, UM and families for their advice and technical support to complete this research.

\section{REFERENCES}

Baldrick, P. 2010. The safety of chitosan as a pharmaceutical excipient. Regulatory Toxicology and Pharmacology 56(3): 290-299.

Bangham, A.D. \& Horne, R.W. 1964. Negative staining of phospholipids and their structural modification by surfaceactive agents as observed in the electron microscope. Journal of Molecular Biology 8(5): 660-IN10.

Çağdaş, M., Sezer, A.D. \& Bucak, S. 2014. Liposomes as potential drug carrier systems for drug delivery. Application of Nanotechnology in Drug Delivery 2014: Article ID. 7181047.

Hardiansyah, A., Yang, M.C., Liu, T.Y., Kuo, C.Y., Huang, L.Y. \& Chan, T.Y. 2017. Hydrophobic drug-loaded PEGylated magnetic liposomes for drug-controlled release. Nanoscale Research Letters 12(1): 1-11.

Jaafar-Maalej, C., Diab, R., Andrieu, V., Elaissari, A. \& Fessi, H. 2010. Ethanol injection method for hydrophilic and lipophilic drug-loaded liposome preparation. Journal of Liposome Research 20(3): 228-243.

Lee, J.S., Choi, H.J., Song, J.H., Ko, H.J., Yoon, K. \& Seong, J.M. 2017. Antiviral activity of itraconazole against echovirus 30 infection in vitro. Osong Public Health and Research Perspectives 8(5): 318-324.

Li, M., Du, C., Guo, N., Teng, Y., Meng, X., Sun, H., Li, S., Yu, P. \& Galons, H. 2019. Composition design and medical application of liposomes. European Journal of Medicinal Chemistry 164: 640-653.

Ling, X., Huang, Z., Wang, J., Xie, J., Feng, M., Chen, Y., Abbas, F., Tu, J., Wu, J. \& Sun, C. 2016. Development of an itraconazole encapsulated polymeric nanoparticle platform for effective antifungal therapy. Journal of Materials Chemistry B 4(10): 1787-1796.

Mady, M.M. \& Darwish, M.M. 2010. Effect of chitosan coating on the characteristics of DPPC liposomes. Journal of Advanced Research 1(3): 187-191.

Mady, M.M., Darwish, M.M., Khalil, S. \& Khalil, W.M. 2009. Biophysical studies on chitosan-coated liposomes. European Biophysics Journal 38(8): 1127-1133.

Mertins, O. \& Dimova, R. 2013. Insights on the interactions of chitosan with phospholipid vesicles. Part II: Membrane stiffening and pore formation. Langmuir 29(47): 1455214559.

Sánchez-Machado, D.I., López-Cervantes, J., Correa-Murrieta, M.A., Sánchez-Duarte, R.G., Cruz-Flores, P. \& de la MoraLópez, G.S. 2019. Chitosan. In Nonvitamin and Nonmineral Nutritional Supplements. Massachusetts: Academic Press.

Suk, V.R.E. \& Misran, M. 2017. Development and characterization of DOPEPEG2000 coated oleic acid liposomes encapsulating anticancer drugs. Journal of Surfactants and Detergents 20(2): 321-329.

Takano, T., Akiyama, M., Doki, T. \& Hohdatsu, T. 2019. Antiviral activity of itraconazole against type i feline coronavirus infection. Veterinary Research 50(1): 1-6.

Tan, H.W. \& Misran, M. 2013. Polysaccharide-anchored fatty acid liposome. International Journal of Pharmaceutics 441(1-2): 414-423.

Teo, Y.Y., Misran, M., Low, K.H. \& Zain, S.M. 2011. Effect of unsaturation on the stability of $\mathrm{C}-18$ polyunsaturated fatty acids vesicles suspension in aqueous solution. Bulletin of the Korean Chemical Society 32(1): 59-64.

Toniazzo, T., Peres, M.S., Ramos, A.P. \& Pinho, S.C. 2017. Encapsulation of quercetin in liposomes by ethanol injection and physicochemical characterization of dispersions and lyophilized vesicles. Food Bioscience 19: 17-25.

Wilson, B., Samanta, M.K., Santhi, K., Kumar, K.S., Ramasamy, M. \& Suresh, B. 2010. Chitosan nanoparticles as a new delivery system for the anti-Alzheimer drug tacrine. Nanomedicine: Nanotechnology, Biology and Medicine 6(1): 144-152.

Department of Chemistry

Faculty of Science

University of Malaya

50603 Kuala Lumpur, Federal Territory

Malaysia

*Corresponding author; email: misni@um.edu.my

Received: 15 October 2019

Accepted: 8 May 2020 